\title{
Anthós
}

$6-21-2021$

\section{The Power of an Unreliable Narrator and the Distortion of Fear in Nella Larsen's Passing}

\author{
Sonia Comstock \\ Portland State University
}

Follow this and additional works at: https://pdxscholar.library.pdx.edu/anthos

Part of the Literature in English, North America Commons Let us know how access to this document benefits you.

\section{Recommended Citation}

Comstock, Sonia (2021) "The Power of an Unreliable Narrator and the Distortion of Fear in Nella Larsen's Passing," Anthós: Vol. 10: Iss. 1, Article 7.

https://doi.org/10.15760/anthos.2021.10.1.7

This open access Article is distributed under the terms of the Creative Commons Attribution-NonCommercialShareAlike 4.0 International License (CC BY-NC-SA 4.0). All documents in PDXScholar should meet accessibility standards. If we can make this document more accessible to you, contact our team. 


\section{The Power of an Unreliable Narrator and the Distortion of Fear in Nella Larsen's Passing}

Sonia Comstock

Nella Larsen's Passing is a novel that examines the struggle of intersectionality through the complicated relationship between two light-skinned Black women during the Harlem Renaissance. The focal characters of the novel are Irene, a steady and responsible woman with deep ties to the Black community, and Clare, a flighty, catlike vixen whose biracial heritage provides her with a strong sense of independence. However, these personalities are portrayed and defined by Irene, who acts as the narrator of the book. Irene fears and hates any kind of want or desire, and that fear strongly plays into her narrative. Her interactions with her husband, Brian, echo this theme, as she constantly quashes his wants and needs in the name of making responsible decisions. Clare and Irene's relationship also heavily reflects this, as Irene loathes and desires Clare in a deeply intertwined way. In this article, I will prove that the depictions of these characters are entrenched in Irene's fear-driven bias and that the plotline of the novel is fundamentally altered when her true personality is understood. To do so, I will compile passages throughout the book that show the judgements she makes of others, as well as the fear, anger, and insecurities that leak from her and influence her point of view. These excerpts will clearly expose Irene's real self and will further demonstrate that understanding Irene is absolutely crucial to understanding the book as a whole.

Many literary scholars have studied the themes of race and homosexuality in Passing, and both aspects have been thoroughly explored. The novel has gained more popularity and recognition in recent years, and numerous academics are now moving beyond these core themes to explore the novel in a deeper, more specific way. Sami Schalk notes that Clare "defies not only the black/white racial binary, but also class, gender and sexual binaries" (Schalk 148). Still, there are very few articles that thoroughly examine who Irene is and how her perspective shifts the novel. A notable exception to this is Claudia Tate's article, "Nella Larsen's 'Passing': A Problem of Interpretation", which focuses on the twisted nature of Irene's narrative. She remarks that "Interpreting Passing can [...] be simplified by defining Irene's role in the story and determining the extent to which she is reliable" (Tate 598). Tate provides a very well-crafted analysis of the novel, but her focus lies on the external relationships that are skewed by Irene's perspective, and does not delve deeply into Irene's inner self. Here, I intend to build on the concept of Irene's unreliability and contribute to the discourse around Passing by providing a previously unexplored and comprehensive examination of Irene's psychology and motivations. 
Irene portrays herself as a serious but generous woman whose faults lie in caring too much about her family. She puts her time into work she sees as helping the Black community and is on the ticket committee of the Negro Welfare League, or as she notes gleefully "I am the committee" (Larsen 70). However, as the novel moves towards its conclusion, it becomes clear that her motives for both her charity work and her familial duties are more selfish and sinister than they seem. Irene is fully laid bare in the final chapter, as it is only towards the very end of the novel that she reckons with herself and realizes what she wants and who she truly is. It is clear that Irene cares greatly about what others think, despite her repeated denials. We see this in many of the interactions that Irene has with Clare. During their chance reunion after several years apart, Irene invites Clare to one of her events in the spur of the moment, but immediately regrets it.

It wasn't, she assured herself, that she was a snob, that she cared greatly for the petty restrictions and distinctions with which what called itself Negro society chose to hedge itself about; but that she had a natural and deeply rooted aversion to the kind of front-page notoriety that Clare Kendry's presence in Idlewild, as her guest, would expose her to. (25)

Irene justifies her dislike for Clare and insists that she isn't a snob, but immediately contradicts that notion by saying Clare would embarrass her. Irene often gets hung up on these "petty restrictions and distinctions"; in fact, much of the evidence shown in this paper will demonstrate how Irene is held up by these structures and defines herself by them.

We see how Irene wants her life to fit into a "proper" order when it is revealed that Irene has pushed her husband, Brian, into becoming a doctor because she sees it as the "right" path to uplift the race, regardless of his deep hatred of it. Larsen writes, "And over his face there came a shadow. 'Lord! How I hate sick people, and their stupid, meddling families, and the smelly, dirty rooms, and climbing filthy steps in dark hallways"' (56-57). Irene then responds to his disdain for the job she forced him into with extreme indignation:

Irene, watching him, was thinking 'It isn't fair, it isn't fair.' After all these years, to still blame her like this. Hadn't his success proved that she'd been right in insisting that he stick to his profession right there in New York?

Couldn't he see, even now, that it had been best? Not for her, oh no, not for her - she had never really considered herself - but for him and the boys. Was she never to be free of it, that fear which crouched, always, deep down within her, stealing away the sense of security, the feeling of permanence, from the life which she had so admirably arranged for them all, and desired so ardently to have remain as it was? That strange, yet fantastic notion of 
Brian's of going off to Brazil, which, though unmentioned, yet lived within him; how it frightened her, and-yes, angered her! (57)

Irene represents herself as a selfless victim of Brian's selfish desire to leave America, which she sees as a deep flaw rather than a legitimate aspiration. Brian wanting to move to Brazil is representative of an escape from American racism, but Irene largely refuses to acknowledge that racism even exists. She has arranged her life in the way that she sees fit and wants to be what she considers an "ideal" member of the Black bourgeoisie and the perfect example of a "New Negro" family. This includes her desire to uplift the race by being on the Negro Welfare League committee and having the "ideal" husband of a Black doctor, a job which he himself clearly despises. It is obvious that she has only one measure of accomplishment and pushes that on everyone else, arguing that Brian's life is a success when he is obviously miserable. As she shows fear towards Brian's wants and anger at the possibility of him not listening to her, she remarks, "It was as if she had admitted to herself that against that easy surface of her husband's concordance with her wishes, which had, since the war had given him back to her physically unimpaired, covered an increasing inclination to tear himself and his possessions loose from their proper setting, she was helpless" (65). Irene appears to regret that her husband was not injured in war, because she would have had more control over him that way. She does not actually care for Brian, only for Brian's role in her life. Near the end of the novel, she finally admits this.

Brian, too, belonged here. His duty was to her and to his boys. Strange, that she couldn't now be sure that she had ever truly known love. Not even for Brian. He was her husband and the father of her sons. But was he anything more? Had she ever wanted or tried for more? In that hour she thought not. Nevertheless, she meant to keep him. (112-113)

Irene does not love Brian, but she needs her life to be a very particular way to be satisfied, so she uses him. She is very willing to hold him back and thwart his dreams for the designated idea of the way her life should be, so she desperately clings to him and her control of him because she is terrified of living in a different way.

As Irene is unmasked, it becomes clear that Clare is not the person Irene says she is. Irene portrays Clare as an almost Machiavellian figure, constantly pointing out her apparent cruelty and manipulations. But once we understand that Irene is not who she advertises herself as, it throws her entire characterization of Clare into question - which is a core example of why understanding Irene is the most vital part of understanding this novel. The first vision of Clare that we get is 
in a flashback that Irene has, and we are immediately shown Clare in the role of a victim:

And for a swift moment, pale small girl sitting on a ragged blue sofa, sewing pieces of bright red cloth together, while her drunken father, a tall, powerfully built man, raged threateningly up and down the shabby room, bellowing curses and making spasmodic lunges at her which were not the less frightening because they were, for the most part, ineffectual. Sometimes he did manage to reach her. (9)

Standing on its own, this passage undeniably portrays Clare as a casualty of her father's abuse and sets her up as someone to be pitied. However, Irene immediately jumps to a very different conclusion. "Clare had known well enough that it was unsafe to take a portion of the dollar [...] but that knowledge had not deterred her. [...] in spite of certain unpleasantness and possible danger, she had taken the money to buy the material for that pathetic little red frock" (10). The red frock acts as a metaphor for the many things that Clare wants, namely wealth and the benefits of passing, and the red color represents both danger and sexuality. We can see how Irene looks down upon Clare's goals as she notes the dress as "pathetic." Clare is willing to put herself in danger to get what she wants, and Irene sees that as a deeply negative trait and blames her for it. Her blame becomes even more drastic in the paragraph that immediately follows, as she notes "there had been, even in those days, nothing sacrificial in Clare Kendry's idea of life, no allegiance beyond her own immediate desire. She was selfish, and cold, and hard" (10). Irene sees a young girl taking her abusive father's money to get the things she wants and does not pity her or look at her with compassion, only with judgement and revulsion-simply because she dared to want something. Irene's demonization of Clare is obvious here, and we can see how Irene blames Clare for the "sin" of wanting.

Clare constantly talks about how lonely she is and how much she misses the Black community. When talking about how seeing Irene again made her want to reconnect to her roots, she says, "It just swooped down and changed everything. If it hadn't been for that, I'd have gone on to the end, never seeing any of you. But that did something to me, and I've been so lonely since! You can't know. Not close to a single soul. Never anyone to really talk to" (68). Clare then starts weeping, and throughout this chapter, we see her voice her unhappiness several times, at one point commenting on how her husband "keeps me out of everything. Everything I want" (72). Clare is married to Jack, a racist white man who does not just discriminate against Black people but actively abhors them. He keeps Clare in her cage of "whiteness" and prevents her from embracing her "Blackness." Clare is no longer happy acting as a white woman in 
society, living a lonely life away from the Black community that she had always longed to be a part of. She wants to reclaim her own heritage and maintain a close relationship with Irene. However, Irene has no sympathy, laying out her worldview, "As far as I can see, you'll just have to endure some things and give up others. As we've said before, everything must be paid for" (72). Irene is not only describing Clare's choices, but also her own-while Clare has sacrificed certain things for her "white" life, Irene has also sacrificed things for her "safe" life within the sphere of the Black community. Irene also has a clear yet heavily repressed attraction to Clare, constantly describing her as beautiful. She calls her "a shade too good looking", "fair and golden [...] with gleaming eyes like a moonlit night" $(71,77)$. Irene hates her attraction to Clare, commenting, "It was as if the woman sitting on the other side of the table, a girl that she had known, who had done this rather dangerous and, to Irene Redfield, abhorrent thing successfully and had announced herself well satisfied, had for her a fascination strange and compelling" (29). Irene finds the fact that Clare passes "abhorrent" (despite passing herself in this very scene), but in a rare moment of honesty, she also admits that she is also extremely taken with her. However, Irene cannot act on her desire for Clare, because doing so would break from her traditional and "secure" life as a member of the Black bourgeoisie. Clare brings out a feeling of wanting in Irene, which terrifies her. This creates the momentum for Irene's constant put-downs of Clare, as she has to push down her "sinful" moments of wanting. Irene hates what Clare represents, and she hates her feelings towards Clare even more. For example, even though Clare constantly states her misery and longing, Irene continues to provide a conflicting perspective on her.

She hadn't the air of a woman whose life had been touched by uncertainty or suffering. Pain, fear, and grief were things that left their mark on people. Even love, that exquisite torturing emotion, left its subtle traces on the countenance. But Clare - she remained almost what she had always been, an attractive, somewhat lonely child—-selfish, willful, and disturbing. (74)

Again, Irene states cruel assumptions that directly contradict what Clare expresses. She brings up Clare's attractiveness, and then immediately follows that up with more vicious attacks towards Clare's feelings.

And it wasn't, as Irene knew, that Clare cared at all about the race or what was to become of it. She didn't. Or that she had for any of its members great, or even real, affection, though she professed undying gratitude for the small kindnesses which the Westover family had shown her when she was a child. Irene doubted the genuineness of it, seeing herself only as a means to an end where Clare was concerned. Nor could it be said that she had even 
the slight artistic or sociological interest in the race that some members of other races displayed. She hadn't. No, Clare Kendry cared nothing for the race. She only belonged to it. (52)

Here, we see Irene continue to invalidate Clare's clearly stated desire to reconnect with members of the Black community, despite Clare remarking on it in nearly every chapter of the novel. Irene has been embedded in the Black bourgeoisie for her entire life, in contrast to Clare, who never fit in because of her lower-class, alcoholic father. Clare was ostracized due to her father's position as a janitor and wants to try to reconnect with the Black community and gain a place there that she never had. Irene completely rejects this idea, seeing Clare as an outsider that does not deserve to be in the Black community because she spent a large amount of her life passing as white. Despite her revulsion towards Clare for existing in white spaces, Irene chooses to pass whenever she wants to. When we are introduced to Irene, she is making her way to an all-white hotel, the Drayton, to have tea after fainting, and that is where she runs into Clare. They meet on the same social level, as they are using the privilege of passing equally. However, Irene believes that only her use of passing is acceptable, and that Clare is not a valid Black person because she chooses to pass. This interaction also tells us that Clare received only "small kindnesses" from a family and that she acted incredibly thankful for them. Irene automatically assumes that this behavior is a falsehood and a manipulation on Clare's part, even though she has no evidence to back that assertion up. Everything Clare has done or said up to this point has actually shown her to be a very pitiable figure. She was abused and mistreated, is consumed with loneliness, and constantly longs for the acceptance from the Black community — which has excluded Clare but embraced Irene.

It is important to note that everyone else in the book likes Clare; Irene is the only one who interprets her actions differently. "She was generally liked. She was so friendly and responsive, and so ready to press the sweet food of flattery on all. Nor did she object to appearing a bit pathetic and ill-used, so that people could feel sorry for her" (82). Clare enjoys also spending time with Irene's servants, which Irene resents and sees as part of "an exasperating childlike lack of perception" (81). Clare, who is the daughter of a janitor and has had to work as a servant to her aunts, has a distinctly less upper-class attitude than Irene, who has lived a consistently comfortable life as an affluent member of the Black bourgeoisie.

Irene is extremely bound by social conventions and rules. Her servants, Zulena, Sadie, and Liza are treated with nothing more than a tight neutrality. Irene seethes at the fact that Clare gets along with them, noting that she would not have "been so friendly with white servants" (81). Mary Wilson, a professor at the University of Massachusetts Dartmouth, wrote an article titled "Working Like a 
Colored Person': Race, Service, and Identity in Nella Larsen's Passing." In it, Wilson discusses Irene's relationship with her servants, pointing out the difference between the uplifted Black bourgeoisie and the working-class Black "cleanup". She also notes that this puts Irene in the more traditionally "white position" of a master to the servants. Wilson comments that in many ways, Clare has had far more common, working-class Black experiences than Irene. Clare was required to do menial and laborious tasks for her aunts, while Irene remained firmly in the upper-class Black bourgeoisie community for her entire life. Irene constantly vilifies Clare for trying to escape her difficult life and gain a higher position in the world, but heavily prizes her own status and uses all of her privileges without a second thought.

At the beginning of the novel, Clare talks about living with her white, devoutly Christian aunts and the hardships she dealt with in their house because of her Blackness, noting the biblical Black figure of Ham: "'Besides, to their notion, hard labor was good for me. I had Negro blood [...] I remember the aunts telling me that that old drunkard had cursed Ham and his sons for all time"" (Larsen 27). Despite Clare's seriousness about the topic, Irene simply laughs at this statement and disregards it. Irene does not outwardly state any struggle about being Black until the end of the novel, when she explicitly echoes Clare's earlier sentiments. She wants to tell Clare's husband that Clare is Black, so that Clare will leave her life, but is reticent to do so because she feels an allegiance to their shared Blackness. "Irene Redfield wished, for the first time in her life, that she had not been born a negro. For the first time she suffered and rebelled because she was unable to disregard the burden of race. [...] It was a brutality, and undeserved. Surely, no other people so cursed as Ham's dark children" (101). Irene wants to block out so many fundamental parts of reality, especially the truth of racism in America and her intense attraction to Clare. Because of her ability to pass for white and the fact that she is heavily entrenched in the relatively safe space of the Black bourgeoisie, Irene has been able to sidestep a lot of the racism that other Black people face. Irene has dealt with racism and been disadvantaged by it, but it was something she was able to push to the periphery of her mind until she met Clare again. Clare exists outside Irene's narrow boundaries, and simply by existing, she forces Irene to see and acknowledge these truths - and Irene absolutely despises her for it.

We see how Irene prefers to pretend racism does not exist through her relationship with her sons. When Brian starts to explain lynching to their children, she absolutely refuses to acknowledge that that racism might be something that they have to deal with, saying that "I want their childhood to be as happy and free from the knowledge of such things as it can possibly be" (108), arguing that hiding from the idea of racism is the only way that they can be happy. Brian brings in the reality of the world, saying, "What was the use of our trying to keep 
them from learning the word 'nigger' and its connotation? They found out, didn't they? And how? Because somebody called Junior a dirty nigger" (108). Despite the overwhelming evidence that racism surrounds her, Irene completely refuses to see any of it. Irene's purposefully narrow view of the world is the largest defense mechanism in her life-and racism is far from the only thing that Irene refuses to see.

The struggle around racial identity is the core theme of the novel, but homoeroticism is also a hugely important factor. As noted earlier in the paper, there is a large amount of evidence that shows that Irene is attracted to Clare, with Irene constantly mentioning Clare's beauty and going into several long monologues about her magnificence.

She'd always had that pale gold hair, which, unsheared still, was drawn loosely back from a broad brow, partly hidden by the small close hat. Her lips, painted a brilliant geranium-red, were sweet and sensitive and a little obstinate. A tempting mouth. The face across the forehead and cheeks was a trifle too wide, but the ivory skin had a peculiar soft lustre. And the eyes were magnificent! Dark, sometimes absolutely black, always luminous, and set in long, black lashes. Arresting eyes, slow and mesmeric, and with, for all their warmth, something withdrawn and secret about them. Ah! Surely! They were Negro eyes! Mysterious and concealing. And set in that ivory face under that bright hair, there was about them something exotic. Yes, Clare Kendry's loveliness was absolute, beyond challenge. (30)

It is a very telling passage in several ways. We see Clare as "partly hidden" and her eyes as both carrying warmth and secrecy, demonstrating the fact that we will never have a full, unobstructed view of Clare. Her Blackness and her whiteness are shown in her features, and they play together in a way that is distinctly mixedrace. However, the clearest part of this description is how it radiates desire. Irene depicts Clare lasciviously, bringing attention to each part of her face. She calls Clare's mouth "tempting", her skin as having a "lustre", and describes her eyes as "mesmeric." Irene is especially drawn to her eyes, which she sees as a representation of the "Negro" in her face. In contrast to her many descriptions of Clare, Irene only describes Brian once.

[She was] looking with a sort of curious detachment at her husband across the room. Brian, she was thinking, was extremely good-looking. Not, of course, pretty or effeminate; the slight irregularity of his nose saved him from the prettiness, and the rather marked heaviness of his chin saved him from the effeminacy. But he was, in a pleasant masculine way, rather handsome. And yet, wouldn't he, perhaps, have been merely ordinarily 
good-looking but for the richness, the beauty of his skin, which was of an exquisitely fine texture and deep copper colour. (54)

Irene instantly comments that Brian is not feminine, making it clear that femininity is innately tied into any notion of attraction that she has. She then points out that she would not see him as handsome without his skin color, which is incredibly indicative of her attitude towards him as a whole. He is not there for support or love, as Brian does not actually matter. He is simply a placeholder for any Black male doctor that she wants to be married to fulfill her dream of being a perfect "New Negro" member of the Black bourgeoisie so that she can live out a "secure" life within those parameters.

In the last section of the book, Irene becomes convinced that Clare and Brian are having an affair, regardless of the complete lack of evidence. Brian treats Clare with a tepid warmth, never showing any particularly strong feelings towards her and looking at her with a type of "tolerant amusement" (81). However, Irene cannot face the fact that Brian is unhappy in their marriage because of her repression of his desires, so instead chooses to project her own feelings towards Clare onto Brian. Irene sees this twisted conclusion as a major revelation, and it causes her to finally reckon with her life and attitude.

Security. Was it just a word? If not, then was it only by the sacrifice of other things, happiness, love, or some wild ecstasy that she had never known, that it could be obtained? And did too much striving, too much faith in safety and permanence, unfit one for these other things? Irene didn't know, couldn't decide, though for a long time she sat questioning and trying to understand. Yet all the while. In spite of her searchings and feeling of frustration, she was aware that, to her, security was the most important and desired thing in life. Not for any of the others, or for all of them, would she exchange it. She wanted only to be tranquil (112).

Clare has made her question her deep attachment to security-representing "happiness, love, or some wild ecstasy" - but in the end, Irene cannot let go of the sacrifices that she's made for her "security." Despite this moment of realization and self-reflection, in the end, she doubles down on her "security" mindset and solidifies her fear-based outlook once and for all. Irene cannot handle dealing with these doubts and sets up Clare's death to avoid seeing this reality. While the final scene leaves the nature of her death somewhat ambiguous - it is unknown if Clare simply fell out of a window or if Irene pushed her. The text heavily implies the latter. Either way, Irene is responsible. She knew that Clare's husband had become aware of Clare's racial origins through an interaction between herself and him, and yet decided not to warn Clare. She needed Clare to die because "she 
couldn't have her free" (116). If Clare got the things she wanted, Irene's "sacrifices of other things" (112) would be rendered invalid, and that would tear down everything for Irene. Irene has clung to "security" her whole life, and as Clare becomes happier and tiptoes on the edge of freedom at the end of the novel-preparing herself for her husband to find out about her Blackness so she can break from him and embrace her heritage-Irene cannot handle it. It would completely undermine Irene's mindset and choices and would show her that the way she was living her life was not the only valid path. She lives in a selfimposed cage of fear and stagnancy in the name of safety and security, and the idea of choosing something different directly threatens the concept that she's living her life the "right" way. Through all her thoughts and interactions with Clare and Brian, there's a common thread: fear and revulsion towards the idea of wanting. To Irene, wanting is a horrible sin and should be punished, and Clare causes Irene to doubt that. "In the look she gave Irene, there was something groping, and hopeless, and yet so absolutely determined that it was like an image of the futile searching and the firm resolution in Irene's own soul, and increased the feeling of doubt and compunction that had been growing within her about Clare Kendry" (73).

Irene initially seems like a self-assured person, but we quickly come to understand that her life, motivations, and perspective are completely warped by fear. Her goal of "security" reflects that, and Clare's upending of her life is not something she can accept in her brittle, cage-like world. Understanding this about Irene is absolutely vital to understanding the novel. If we take Irene at face value, she appears to be the only sane woman among self-centered, awful people who want to undermine her way of life. However, a deeper study of her proves that she is a selfish, fearful, and sad person who denies herself the things that she wants and resents others for choosing not to suppress their own desires. It leads to a drastically different reading of the novel and forces the reader to realize that the characters that surround Irene are entirely different from the way that she portrays them. This completely changes the dynamic of Passing, and it unearths the fearbased attitudes around race and homosexual attraction that lie beneath the veneer of Irene's narration. If Irene's judgments are taken at face value, the book appears to be a narrow, shallow portrayal of simple relationships. But once Irene's twisted mindset and profound unreliability are fully understood, Passing becomes a complex, meaningful story that deftly explores the tangled relationship between intersectionality, fear, and wanting. 


\section{References}

Larsen, Nella. Passing. Alfred A. Knopf Inc., 1929.

Schalk, Sami. "Transing: Resistance to Eugenic Ideology in Nella Larsen's Passing." Journal of Modern Literature, vol. 38, no. 3, 2015, pp. 148-161.

Tate, Claudia. "Nella Larsen's Passing: A Problem of Interpretation." African American Review, vol. 50, no. 4, 2017, pp. 597-601.

Wilson, Mary. “'Working Like a Colored Person': Race, Service, and Identity in Nella Larsen's Passing.” Women's Studies, vol. 42, 2013, pp. 979-1009. 